\title{
Analisis Faktor-Faktor yang Mempengaruhi Keberhasilan Studi Mahasiswa di PTKIN Provinsi Jawa Tengah
}

\author{
Nalim $^{1^{*}}$, Heni Lilia Dewi ${ }^{2}$, Muhammad Aris Safii ${ }^{3}$ \\ ${ }^{1 *, 2}$ Tadris Matematika, Fakultas Tarbiyah dan Ilmu Keguruan, ${ }^{3}$ Ekonomi Syariah, Fakultas \\ Ekonomi dan Bisnis Islam, Institut Agama Islam Negeri Pekalongan \\ *Corresponding Author. Email: yusufnalim@iainpekalongan.ac.id
}

\begin{abstract}
This study aims to determine the factors that influence academic achievement and student study period. The method used in this research is ex-post facto qualitative research, with a comparative model that compares several similar variables. The sample involved was 398 students from five State Islamic Universities in Central Java. Samples were selected using the random sampling method. Data collection techniques used are observation and documentation. The data obtained were analyzed using one-way ANOVA and multiple linear regression. The results showed that: (a) Only two of the six factors had a significant effect on student achievement, that was gender and the new student's admission way. (b) There were four of the seven factors that significantly affected the study period, that was gender, type of high school, GPA, and PMB wayway. (c) There was a significant difference in student achievement in terms of the new student's admission way. The highest academic achievement (GPA) was achieved by students who are accepted through the National Academic Achievement Selection Wayway of State Islamic Religious Colleges with an average of 3.61. d) There was a significant difference in the study period in terms of the wayway for new students. The fastest study period was reached by students who were accepted through the State Islamic Religious College Entrance Examination way with an average of 8.5 semesters. (e) There was a very significant negative correlation (sig. $=0,000$ ) between the GPA and the study period, which means that the higher the student GPA, the faster the study period.
\end{abstract}

Abstrak: Penelitian ini bertujuan untuk mengkaji faktor-faktor yang mempengaruhi prestasi akademik dan masa studi mahasiswa. Metode yang digunakan dalam penelitian ini yaitu penelitian kualitatif ex post facto, dengan model komparatif yang membandingkan beberapa variabel yang sejenis. Sampel yang terlibat adalah 398 mahasiswa dari lima Perguruan Tinggi Agama Islam Negeri (PTKIN) di Jawa Tengah. Sampel dipilih menggunakan metode random sampling. Teknik pengumpulan data yang digunakan yaitu observasi dan dokumentasi. Data yang diperoleh dianalisis menggunakan one-way ANOVA dan regresi linier berganda. Hasil penelitian menunjukkan bahwa: (a) Hanya dua dari enam faktor yang berpengaruh signifikan terhadap prestasi mahasiswa, yaitu jenis kelamin dan jalur PMB, (b) Ada empat dari tujuh faktor yang secara signifikan mempengaruhi masa studi, yaitu jenis kelamin, jenis sekolah tinggi, IPK, dan jalur PMB, (c) Terdapat perbedaan prestasi mahasiswa yang signifikan ditinjau dari hal jalur penerimaan mahasiswa baru. Prestasi akademik tertinggi (IPK) dicapai oleh mahasiswa yang diterima melalui jalur Seleksi Prestasi Akademik Nasional Perguruan Tinggi Keagamaan Islam Negeri (SPAN-PTKIN) dengan rata-rata 3,61, d) Terdapat perbedaan masa studi yang signifikan dilihat dari jalur penerimaan mahasiswa baru. Periode studi tercepat dicapai oleh mahasiswa yang diterima melalui jalur Ujian Masuk Perguruan Tinggi Keagamaan Islam Negeri (UMPTKIN) dengan rata-rata 8,5 semester, (e) Terdapat korelasi negatif yang sangat signifikan (sig. = 0,000) antara IPK dan masa studi, yang berarti bahwa semakin tinggi IPK mahasiswa, semakin cepat masa studi.

\section{Article History}

Received: 18-01-2021

Revised: 02-05-2021

Accepted: 01-10-2021

Published: 11-12-2021

\section{Key Words:}

Admission Way,

Academic

Achievement,

Study Period.

\section{Sejarah Artikel}

Diterima: 18-01-2021

Direvisi: 02-05-2021

Disetujui: 01-10-2021

Diterbitkan: 11-12-2021

Kata Kunci:

Jalur PMB,

Prestasi Akademik, Masa

Studi. 
How to Cite: Nalim, N., Dewi, H., \& Safii, M. (2021). Analisis Faktor-Faktor yang Mempengaruhi Keberhasilan Studi Mahasiswa di PTKIN Provinsi Jawa Tengah. Jurnal Kependidikan: Jurnal Hasil Penelitian dan Kajian Kepustakaan di Bidang Pendidikan, Pengajaran dan Pembelajaran, 7(4), 1003-1013. doi:https://doi.org/10.33394/jk.v7i4.3430

https://doi.org/10.33394/jk.v7i4.3430

This is an open-access article under the CC-BY-SA License.

\section{Pendahuluan}

Prestasi akademik merupakan salah satu tolok ukur keberhasilan seseorang menempuh pendidikan dan menjadi ukuran kualitas lulusan. Prestasi akademik juga memainkan peranan penting dalam menghasilkan lulusan berkualitas yang akan menjadi SDM unggul dan calon pemimpin yang hebat serta bertanggung jawab atas pembangunan ekonomi dan sosial suatu negara. Salah satu faktor utama yang dipertimbangkan oleh perusahaan/industri dalam menerima tenaga kerja baru adalah prestasi akademik calon pekerja. Sebuah situs resmi menyebutkan bahwa mahasiwa yang lulus dengan indeks prestasi kumulatif (IPK) minimal 3,25 ke atas cenderung diminati perusahaan besar di Indonesia (https://mediaindonesia.com). Kesiapan memasuki dunia kerja memang perlu didukung oleh kemampuan akademis yang baik (Muspawi, dkk, 2020). Nilai IPK yang tinggi diasumsikan bahwa mahasiswa tersebut sukses memahami teori dan aplikasi dengan baik. Untuk sejumlah posisi pekerjaan yang mengutamakan keahlian secara spesifik, IPK bisa dibilang cukup penting" . Di sisi lain, prestasi akademik di dalam dunia pendidikan juga menjadi salah satu syarat dalam melanjutkan studi dan juga syarat sebagai guru/dosen. Bahkan, menurut Suwena (2017) prestasi akademik dijadikan sebagai salah satu syarat masuk siswa memasuki jenjang pendidikan selanjutnya. Prestasi akademik mahasiswa juga menentukan kualitas pendidikan berikutnya, karena para alumni perguruan tinggi akan menjadi guru pada level pendidikan di bawahnya, seperti SMA, SMP atau SD, bahkan sampai tingkat pendidikan pra sekolah (TK dan PAUD).

Banyak faktor yang dapat menghambat dan menjadi katalis bagi mahasiswa untuk mencapai prestasi akademik yang baik. Faktor yang mempengaruhi setiap prestasi belajar mahasiswa atau IP juga berbeda-beda (Saputro, dkk, 2015). Menurut Suryabrata (2001), faktor yang mempengaruhi prestasi akademik terbagi menjadi faktor eksternal non sosial dan sosial. Faktor non-sosial meliputi keadaan udara, suhu udara, cuaca, waktu, tempat, alat-alat yang dipakai untuk belajar, gedung kampus dan letaknya, rumah tempat tinggal individu tersebut, alat-alat belajar yang digunakan, keadaan cuaca dan waktu belajar yang digunakan seseorang. Faktor ini secara langsung dapat mempengaruhi psikologis seseorang yang berakibat pada hasil prestasi yang akan didapat pada mahasiswa. Adapun faktor sosial adalah faktor manusia yang dapat berupa para dosen, senior, dan teman-teman sekelas lainnya serta lingkungan sosial sekitar rumah juga mempengaruhi seseorang untuk mencapai prestasi akademik, seperti dukungan orangtua dan lingkungan tetangga. Faktor sikap orangtua terhadap anak, sikap guru terhadap peserta didik, dan self-regulated learning berpengaruh terhadap prestasi belajar peserta didik (Yuzarion, 2017).

Beberapa penelitian telah dilakukan untuk mengeksplorasi faktor-faktor yang mempengaruhi prestasi akademik mahasiswa. Salah satu faktor utama adalah kecerdasan mahasiswa. Hal ini sejalan dengan pendapat Syafií, dkk (2018) yang mengatakan bahwa faktor-faktor yang mempengaruhi pretasi belajar adalah antara lain sebagai berikut: (1) pengaruh pendidikan dan pembelajaran unggul; (2) perkembangan dan pengukuran otak, dan (3) kecerdasan (intelegensi) emosional. Pendapat lain juga ditegaskan oleh Sulasmi (2020) bahwa faktor yang mempengaruhi prestasi belajar dilihat dari aspek manajemen belajar 
siswa, yakni rajin dalam belajar, tekun dalam belajar, rajin mengerjakan tugas, memiliki jadwal belajar, disiplin dalam belajar.

Mckenzie dan Schweitzer (2001) melakukan penelitian prospektif untuk mengeksplorasi prediktor psikososial, kognitif, dan demografi terhadap prestasi akademik mahasiswa tahun pertama di Australia. Hasilnya menunjukkan bahwa prestasi akademik di sekolah menengah diidentifikasi sebagai prediktor yang paling signifikan terhadap prestasi akademik mahasiswa. Integrasi ke dalam universitas, efikasi diri, dan tanggung jawab ketenagakerjaan juga merupakan prediktor prestasi mahasiswa. Riset Hijazi dan Naqvi (2006) berfokus untuk mengeksplorasi faktor-faktor yang terkait dengan prestasi mahasiswa dalam ujian lanjutan. Kesimpulannya bahwa tingkat kehadiran di kelas, alokasi waktu untuk belajar, tingkat pendapatan orang tua, usia ibu dan pendidikan ibu adalah faktor utama yang mempengaruhi prestasi akademik mahasiswa pada perguruan tinggi swasta. Lemahnya kemampuan dasar peserta didik pada konsep matematika yang dimiliki terutama kurang menguasai materi prasyarat juga menjadi faktor penghambat utama peserta didik (Fitrah, 2015).

Selain prestasi akademik, hal penting lain yang perlu dikaji dari seorang mahasiswa adalah masa studi. Penyelenggarakan pendidikan yang berkualitas dan berkesinambungan perlu menguoayakan setiap program studi perlu melakukan evaluasi terhadap efektivitas dan produktivitas pendidikan, salah satunya dengan menggunakan indikator masa studi (Rahmi \& Yozza, 2020). Masa studi adalah waktu terjadwal yang harus ditempuh oleh mahasiswa sesuai dengan rentang waktu yang dipersyaratkan. Masa studi merupakan lamanya waktu yang butuhkan oleh mahasiswa dari masuk kuliah hingga lulus. Pada jenjang sarjana, masa studi yang ditempuh mahasiswa tidak boleh melebihi 14 semester. Masa studi sangat penting untuk diperhatikan sebab hal ini menjadi salah satu butir penilaian dalam akreditasi. Di samping itu, masa studi juga dapat dikaitkan dengan kualitas perguruan tinggi. Perguruan tinggi yang bagus, maka rata-rata masa studi mahasiswanya cenderung lebih pendek. Masa studi merupakan tolok ukur kelulusan tepat waktu. Pada jenjang sarjana, dikatakan lulus tepat waktu apabila mahasiswa mampu lulus dalam kurun waktu empat tahun. Apabila prosentase kelulusan tepat waktu melebihi 50\%, maka akan memperoleh skor yang sangat baik/maksimum. Lama masa studi mahasiswa, akan mengakibatkan skor butir ini semakin kecil (BAN-PT, 2011).

Penelitian ini tidak hanya menganalisis faktor-faktor yang mempengaruhi prestasi akademik mahasiswa saja, namun juga akan menganalisis faktor-faktor yang mempengaruhi masa studi. Meskipun antara prestasi akademik dengan masa studi terkesan berkorelasi, namun hasil analisis nantinya akan melihat apakah ada perbedaan dalam hal faktor-faktor lainnya. Secara lebih jelas akan dikupas pada bagian pembahasan. Penelitian ini juga memberikan perbedaan dalam hal variabel bebas yang jarang digunakan sebelumnya, yakni: status sekolah menengah, jurusan sekolah menengah, jenis kelamin. Sementara itu dua faktor lainnya yaitu jalur seleksi penerimaan mahasiswa masuk (PMB), asal sekolah menengah sudah pernah diteliti oleh Muslimin (2012) dan beberapa peneliti lain namun dengan indikator dan analisis yang berbeda.

Adapun tujuan penelitian ini adalah untuk menganalisis tentang faktor-faktor yang mempengaruhi keberhasilan studi mahasiswa, utamanya adalah mahasiswa PTKIN di Provinsi Jawa Tengah. Dengan demikian, akan ada gambaran dan perbaikan mengenai sistem pendidikan sehingga dapat mengoptimalkan keberhasilan studi mahasiswa. 


\section{Metode Penelitian}

Metode yang digunakan dalam penelitian ini adalah penelitian kualitatif ex post facto, dengan model komparatif yang membandingkan beberapa variabel yang sejenis, yaitu keberhasilan mahasiswa menurut jalur masuk, jenis kelamin dan pendidikan sebelumnya. Prestasi belajar diukur dengan IPK mahasiswa, sedangkan masa studi diukur dengan jumlah semester yang ditempuh mahasiswa. Varibel jalur PMB terdiri dari enam yaitu SPANPTKIN, UM-PTKIN, TES MANDIRI, MINAT/BAKAT, SBMPTN, SNMPTN. Variabel asal sekolah menengah terdiri dari SMA, SMK, MA, dan lainnya (Pondok Pesantren). Status sekolah menengah dibedakan menjadi negeri dan swasta. Jurusan di sekolah menengah terdiri IPA, IPS, Bahasa dan Agama. Sedangkan jenis kelamin terdiri dari Laki-laki dan Perempuan.

Penelitian ini dilakukan di beberapa PTKIN di Jawa Tengah. Populasi dalam penelitian ini adalah seluruh mahasiswa PTKIN di Jawa Tengah. Sampel dipilih menggunakan rumus Lemeshow (Nalim, 2015) dan dengan persentase kelonggaran 5\% diperoleh sampel sebanyak 398 mahasiswa dari total populasi. Teknik pengumpulan data yang digunakan dalam penelitian ini yaitu observasi dan dokumentasi. Sedangkan Teknik analisis datanya menggunakan menggunakan one-way anova dan regresi linier berganda. Regresi linear berganda adalah metode statistik untuk menguji pengaruh variabel dependen dengan lebih dari satu variabel (Gozali \& Nasehudin, 2012).

\section{Hasil Penelitian dan Pembahasan}

Berdasarkan hasil pengumpulan dokumen diperoleh data tentang identitas diri mahasiswa, asal dan status sekolah, jurusan di sekolah sebelumnya, jalur masuk PTKI, IPK dan masa studi mahasiswa. Data disajikan dalam Tabel 1 berikut ini.

Tabel 1. Profil Responden

\begin{tabular}{llcc}
\hline \multicolumn{1}{c}{ Aspek } & \multicolumn{1}{c}{ Kriteria } & Jumlah & Persentase \\
\hline \multirow{2}{*}{ Jenis Kelamin } & Laki-laki & 116 & $29 \%$ \\
& Perempuan & 282 & $71 \%$ \\
\hline \multirow{3}{*}{ Asal Sekolah } & SMA & 135 & $34 \%$ \\
& SMK & 56 & $14 \%$ \\
& MA & 197 & $49 \%$ \\
\multirow{2}{*}{ Status Sekolah } & Lainnya & 10 & $3 \%$ \\
\hline \multirow{5}{*}{ Jurusan di sekolah } & Negeri & 226 & $57 \%$ \\
menengah & Swasta & 172 & $43 \%$ \\
& IPA & 183 & $46 \%$ \\
& IPS & 126 & $32 \%$ \\
& Bahasa & 9 & $2 \%$ \\
& Agama & 24 & $6 \%$ \\
& Akuntansi & 16 & $4 \%$ \\
\multirow{5}{*}{ Jalur PMB } & Lainnya & 40 & $10 \%$ \\
& SPAN-PTKIN & 49 & $12 \%$ \\
& UM-PTKIN & 40 & $10 \%$ \\
& Mandiri & 239 & $60 \%$ \\
\hline \multirow{2}{*}{ IPK } & Minat/ Bakat & 30 & $7 \%$ \\
& SBMPTN & 29 & $7 \%$ \\
& SNMPTN & 11 & $3 \%$ \\
\hline & $3,10-3,27$ & 29 & $7 \%$ \\
& $3,28-3,44$ & 85 & $21 \%$
\end{tabular}




\begin{tabular}{rccc}
\hline Aspek & Kriteria & Jumlah & Persentase \\
\hline & $3,45-3,60$ & 137 & $34 \%$ \\
$3,61-3,77$ & 122 & $31 \%$ \\
$3,78-3,94$ & 25 & $6 \%$ \\
\hline 7 semester & 18 & $5 \%$ \\
Masa Studi & 8 semester & 189 & $47 \%$ \\
& 9 semester & 106 & $27 \%$ \\
& 10 semester & 69 & $17 \%$ \\
& 11 semester & 3 & $1 \%$ \\
& 12 semester & 9 & $2 \%$ \\
& 13 semester & 1 & $0 \%$ \\
& 14 semester & 3 & $1 \%$ \\
\hline
\end{tabular}

Karakteristik responden dapat dilihat sebagaimana terlihat pada Tabel 1 dapat digambarkan sebagai berikut. Responden didominasi oleh perempuan sebanyak 282 mahasiswa (71\%) dan responden laki-laki sebanyak 116 mahasiswa (29\%). Asal sekolah responden didominasi oleh responden yang berasal dari MA, yaitu sebanyak 197 mahasiswa (49\%). Terbanyak kedua berasal dari SMA, 135 responden (34\%). Di sisi lain, SMK menjadi penyuplai asal mahasiswa ketiga, sebanyak 56 (14\%). Sementara itu, 3\% responden berasal dari Lainnya (Pondok pesantren, PGA dan paket C). Dominasi Madrasah Aliyah (MA) sebagai penyuplai utama memang tidak aneh bgi PTKIN, karena tidak dapat dipungkiri, bahwa salah satu tujuan hadirnya PTKIN adalah untuk menampung para alumni MA dan pondok pesantren. Namun belakangan ini, seiring meningkatnya status kelembagaan PTKIN menjadi universitas dan institut, yang kemudian membuka peluang didirikannya program studi non keagamaan (umum), menyebabkan semakin banyaknya alumni SMA maupun SMK yang masuk ke PTKIN.

Jalur "ujian mandiri" mendominasi PMB dengan responden sebanyak 239 (60\%). Berikutnya berturut-turut adalah jalur SPAN-PTKIN, UM-PTKIN, Minat/Bakat, SBMPTN dan terakhir adalah SNMPTN. Dua jalur terakhir merupakan jalur yang diselenggarakan oleh Kementerian Riset Teknologi dan Pendidikan Tinggi, yang mana PTKIN yang bisa masuk ke jalur tersebut hanyalan UIN Walisongo Semarang, sehingga wajar bila respondennya sangat sedikit. Distribusi IPK responden tergolong baik, hal ini disebabkan mayoritas berada pada interval IPK 3,45-3,60 (34\%) dan interval 3,61-3,77 (31\%). Sedangkan Masa studi yang ditempuh kebanyakan responden adalah adalah 8 semester $(47 \%)$.

\section{Uji ANOVA Perbedaan IPK Antar Jalur Seleksi}

\section{Tabel 2. Hasil Uji-F}

\begin{tabular}{cccccc}
\hline Source & Sum of Squares & df & Mean Square & F & Sig. \\
\hline Between Groups & .748 & 6 & .125 & 4.609 & .000 \\
\hline Within Groups & 10.581 & 391 & .027 & & \\
\hline Total & 11.329 & 397 & & & \\
\hline
\end{tabular}

Hasil uji ANOVA perbedaan IPK antara enam jalur penerimaan yaitu SPANPTKIN, UMPTKIN, Mandiri, Minat/Bakat, SBMPTN, SNMPTN. Dari tabel tersebut dapat kita lihat bahwa nilai Sig. sebesar 0,000. Dengan demikian pada taraf nyata 5\% kita menolak Ho, sehingga kesimpulan yang didapatkan adalah terdapat perbedaan yang bermakna rata-rata IPK berdasarkan ketujuh jalur penerimaan tersebut. 


\section{Uji ANOVA Perbedaan Masa Studi Antar Jalur Seleksi}

Rata-rata masa studi tercepat adalah jalur UMPTKIN (8,25 semester). Tercepat kedua adalah jalur SPANPTKIN (8,39 semester). Tercepat ketiga adalah jalur SBMPTN $(8,52$ semester), tercepat keempat adalah jalur Minat/Bakat (8,57 semester), tercepat kelima adalah jalur Mandiri Tes $(8,85$ semester), tercepat keenam adalah jalur PSSB $(9,56)$ dan yang paling lambat lulus adalah jalur SNMPTN (10 semester).

Tabel 3. Hasil Uji-F

\begin{tabular}{cccccc}
\hline Source & Sum of Squares & df & Mean Square & F & Sig. \\
\hline Between Groups & 48.813 & 6 & 7.302 & 6.445 & .000 \\
\hline Within Groups & 443.011 & 391 & 1.133 & & \\
\hline Total & 486.824 & 397 & & & \\
\hline
\end{tabular}

Hasil uji ANOVA perbedaan masa studi antara tujuh jalur penerimaan yaitu SPANPTKIN, UM-PTKIN, MANDIRI TES, MINAT/BAKAT, SBMPTN, SNMPTN, PSSB. Berdasarkan Tabel 2 dapat kita lihat bahwa nilai Sig. diperoleh nilai $\mathrm{p}(p$-value $)=0,000$. Dengan demikian pada taraf nyata 5\% kita menolak Ho, sehingga kesimpulan yang didapatkan adalah terdapat perbedaan yang bermakna rata-rata masa studi berdasarkan ketujuh jalur penerimaan tersebut.

Karena hasil uji ANOVA menunjukan adanya perbedaan yang bermakna, maka uji selanjutnya adalah melihat kelompok mana saja yang berbeda. Untuk menentukan uji lanjut mana yang digunakan, maka kembali kita lihat hasil Test of Homogeneity of Variances, bila hasil tes menunjukan varian sama, maka uji lanjut yang digunakan adalah uji Bonferroni. Namun bilai hasil tes menunjukan varian tidak sama, maka uji lanjut yang digunakan adalah uji Games-Howell.

Berdasarkan hasil Test of Homogenity menghasilkan bahwa varian ketiga kelompok tersebut sama, maka uji lanjut (Post-Hoc Test) yang digunakan adalah Uji Bonferroni. Nilai Post-Hoc Test memperlihatkan bahwa kelompok yang menunjukan adanya perbedaan ratarata Masa Studi, yaitu: (1) Jalur SPAN-PTKIN dan jalur SNMPTN, dengan nilai difference sebesar -1.612 dan nilai signifikansi sebesar 0,000; (2) Jalur UM-PTKIN dan jalur MANDIRI TES, dengan nilai difference sebesar-.595-1.155 dan nilai signifikansi sebesar 0,024; (3) Jalur UM-PTKIN dan jalur SNMPTN, dengan nilai difference sebesar -1.750 dan nilai signifikansi sebesar 0,000; dan (4) Jalur UM-PTKIN dan jalur PSSB, dengan nilai difference sebesar -1.306 dan nilai signifikansi sebesar 0,020.

\section{Korelasi antara Masa Studi dengan IPK}

Nilai Sig. (2-tailed) sebesar 0,000. Nilai ini kurang dari 0,05 (taraf signifikan 5\%), bahkan kurang dari 0,01 (1\%), yang mengakibatkan Ho ditolak. Karena Ho ditolak, maka kesimpulannya adalah terdapat hubungan (korelasi) yang sangat signifikan antara IPK dengan masa studi mahasiswa.

Tabel 4. Hasil Uji Korelasi Pearson

\begin{tabular}{clcc}
\hline & Correlations & IPK & Masa Studi \\
\hline \multirow{2}{*}{ IPK } & Pearson Correlation & 1 & $-.345^{* *}$ \\
& Sig. (2-tailed) & & .000 \\
& $\mathrm{~N}$ & 398 & \\
\hline \multirow{2}{*}{ Masa Studi } & Pearson Correlation & $-.345^{* *}$ & 1 \\
& Sig. (2-tailed) & .000 & 398 \\
& $\mathrm{~N}$ & & \\
\hline
\end{tabular}




\section{Uji Regresi Linier Berganda: Faktor-faktor yang Mempengaruhi IPK (Prestasi)}

Uji F (Uji Kesesuaian Model)

Uji F (disebut juga uji simultan) merupakan tahapan awal mengidentifikasi model regresi yang diestimasi layak atau tidak. Layak (andal) disini maksudnya adalah model yang diestimasi layak digunakan untuk menjelaskan pengaruh variabel-variabel bebas terhadap variabel terikat. Nama uji ini disebut sebagai uji F, karena mengikuti mengikuti distribusi F yang kriteria pengujiannya seperti One-Way Anova.

Tabel 5. Hasil Uji- $F$ ANOVA ${ }^{b}$

\begin{tabular}{cccccc}
\hline Model & Sum of Squares & df & Mean Square & F & Sig. \\
\hline Regression & .360 & 6 & .060 & 2.139 & $.048^{\mathrm{a}}$ \\
Residual & 10.969 & 391 & .028 & & \\
Total & 11.329 & 397 & & & \\
\hline
\end{tabular}

a.Predictors: (Constant), JEDA,JALUR,STATUSSM, JURSM,JK,ASALSM

b.Dependent Variable: Prestasi

Berdasarkan uji anova (Tabel 5), nilai $\mathrm{F}$ sebesar 2,139 dengan nilai signifikansi 0,048, karena nilai signifikansi $<0,05$, sehingga Ho ditolak dan menerima Ha, sehingga hipotesis yang menyatakan ada pengaruh positif antara jenis kelamin, asal sekolah, status sekolah, jeda kuliah, jalur PMB, jurusan di sekolah terhadap Prestasi Akademik dapat diterima.

Hasil uji F dapat dilihat pada tabel ANOVA 4.35 di atas menunjukkan bahwa nilai prob. F hitung terlihat pada kolom terakhir (sig.) sebesar 0,048, kurang dari dari tingkat signifikansi 0,05 sehingga dapat disimpulkan bahwa model regresi linier yang diestimasi layak digunakan untuk menjelaskan pengaruh Masa Jeda setelah Lulus SMA sampai Mendaftar Sarjana (JEDA), Jenis Kelamin (JK), Jalur Seleksi Masuk (JALUR), Status sekolah menengah (STATUSSM), Jurusan di sekolah menengah (JURSM), dan Asal sekolah menengah (ASALSM) terhadap Prestasi (IPK).

Tabel 6. Hasil Uji-t

\begin{tabular}{|c|c|c|c|c|c|}
\hline \multirow{2}{*}{ Model } & \multicolumn{2}{|c|}{$\begin{array}{c}\text { Unstandardized } \\
\text { Coefficients }\end{array}$} & \multirow{2}{*}{$\begin{array}{c}\text { Stantardized } \\
\text { Coefficients }\end{array}$} & \multirow{2}{*}{$\mathbf{t}$} & \multirow{2}{*}{ Sig. } \\
\hline & B & $\begin{array}{l}\text { Std. } \\
\text { Eror }\end{array}$ & & & \\
\hline 1 (Constant) & 3.554 & .050 & & 71.092 & .000 \\
\hline Jenis Kelamin & .038 & .019 & .102 & 2.002 & .046 \\
\hline Asal Sekolah & -.007 & .009 & -.041 & -.789 & .431 \\
\hline Status Sekolah & .002 & .018 & .006 & .112 & .911 \\
\hline Jeda Kuliah & .001 & .008 & .006 & .109 & .913 \\
\hline Jalur PMB & -.017 & .007 & -.124 & -2.478 & .014 \\
\hline Jurusan di Sekolah & -.006 & .005 & -.061 & -1.207 & .228 \\
\hline \multicolumn{6}{|c|}{ a.Dependent Variable: IPK } \\
\hline \multicolumn{6}{|c|}{$\begin{array}{l}\text { Pengaruh jenis kelamin terhadap prestasi akademik mahasiswa, berdasarkan Tabel } 6 \\
\text { jukkan bahwa hasil uji-t diperoleh nilai t-hitung } 2,002 \text { dengan nilai signifikansi } 0,046 \\
\text {. Ini berarti Ho ditolak dan Ha diterima, sehingga hipotesis yang menyatakan ada } \\
\text { uh positif signifikan antara jenis kelamin terhadap prestasi akademik mahasiswa dapat } \\
\text { al. Lain halnya, faktor asal sekolah menengah ternyata tidak berpengaruh terhadap } \\
\text { i. akademik mahasiswa, hal ini dapat dilihat pada Tabel } 6 \text { yang menunjukkan bahwa } \\
\text { hitung sebesar }-0,789 \text { dengan nilai signifikansi } 0,431>0,05 \text {. Adapun faktor status } \\
\text { h, jeda kuliah dan jurusan di sekolah juga tidak berpengaruh signifikan terhadap } \\
\text { si akademik mahasiswa. Hal ini dapat dilihat pada nilai Signifikansi berturut-turut }\end{array}$} \\
\hline
\end{tabular}


sebesar 0.112, 0.109, dan -1.207. yang mana nilai-nilai ini lebih besar dari 0,05. Di sisi lain, ada satu faktor lagi yang berpengaruh sigifikan terhadap prestasi akademik mahasiswa yaitu jalur PMB. Nilai t hitung yang diperoleh sebesar -2,478 dengan signifikansi 0,014<0,05.

\section{Uji Regresi Linier Berganda: Faktor-faktor yang Mempengaruhi Masa Studi}

Tabel 7. Hasil Uji-F

\begin{tabular}{cccccc}
\hline Model & Sum of Squares & df & Mean Square & F & Sig. \\
\hline Regression & 99.539 & 7 & 14.220 & 14.319 & $.000 \mathrm{a}$ \\
Residual & 387.286 & 390 & .993 & & \\
Total & 486.824 & 397 & & & \\
\hline
\end{tabular}

a.Predictors: (Constant), Prodi,Jalur PMB,Asal Sekolah, IPK,Jeda,Status Sekolah,Jenis Kelamin

b.Dependent Variable: Masa Studi

Nilai signifikasi uji $\mathrm{F}$ di atas sebesar 0,000. Nilai ini kurang dari dari 0,05, bahkan kurang dari dari 0,01. Artinya, (secara simultan) bahwa semua variabel bebas memiliki pengaruh yang sangat signifikan terhadap variabel terikat (Masa Studi). Makna lain juga berarti bahwa model yang diestimasi telah sesuai. Atau model ini sangat layak untuk menggambarkan hubungan antar variabel bebas terhadap variabel terikatnya.

Tabel 8. Hasil Uji-t

\begin{tabular}{clcccc}
\hline \multirow{2}{*}{ Model } & \multicolumn{2}{c}{$\begin{array}{c}\text { Unstandardized } \\
\text { Coefficients }\end{array}$} & $\begin{array}{c}\text { Stantardized } \\
\text { Coefficients }\end{array}$ & T & Sig. \\
\cline { 2 - 4 } & $\mathbf{B}$ & $\begin{array}{c}\text { Std. } \\
\text { Eror }\end{array}$ & Beta & & \\
\hline 1 (Constant) & 15.755 & 1.107 & & 14.230 & .000 \\
\hline Jenis Kelamin & -.399 & .116 & -.164 & -3.425 & .046 \\
\hline Asal Sekolah & .110 & .055 & .094 & 2.002 & .431 \\
\hline Status Sekolah & .169 & .105 & .075 & 1.606 & .911 \\
\hline IPK & -1.996 & .301 & -.304 & -6.638 & .913 \\
\hline Jeda Kuliah & -.050 & .044 & -.053 & -1.135 & .014 \\
\hline Jalur PMB & .135 & .041 & .152 & 3.315 & .228 \\
\hline Prodi & -.022 & .013 & -.081 & -1.725 & \\
\hline
\end{tabular}

a.Dependent Variable: Masa Studi

Hasil uji individu antar variabel bebas terhadap variabel terikat, pada kolom signifikansi, terlihat bahwa empat variabel bebas yang memiliki nilai sig. Kurang dari 0,05 yakni Jenis Kelamin $(0,001)$, Asal Sekolah Menengah $(0,046)$, IPK $(0,000)$ dan Jalur $(0,001)$. Artinya, keempat variabel inilah yang signifikan pengaruhnya terhadap Masa Jeda.

\section{Analisis pengaruh jalur penerimaan mahasiswa baru terhadap prestasi belajar mahasiswa}

Berdasarkan hasil analisis regresi berganda, diperoleh bahwa jalur penerimaan mahasiswa baru berpengaruh signifikan terhadap prestasi belajar mahasiswa. Hal ini dibuktikan dengan nilai signifikansi 0,14. Nilai koefisien menunjukan tanda negatif, menandakan semakin besar poin jalur seleksi masuk, akan menurunkan prestasi akademik. Posisi poin jalur yang pertama (yang paling kecil) adalah SPAN-PTKIN, UM-PTKIN, Jalur Mandiri Tes, Jalur Mandiri Bakat, SBMPTN dan SNMPTN. Ini mengartikan bahwa jalur seleksi yang memiliki prestasi akademik baik adalah mahasiswa yang diterima melalui jalur SPAN-PTKIN dan UMPTKIN. 
Hasil penelitian ini sesuai dengan hasil penelitian Muslimin (2012) yang meneliti pengaruh jalur masuk, TPA dan asal sekolah terhadap prestasi belajar. Hanya saja jalur masuk yang maksud oleh Immawan (2012) adalah jalur TPA dan Non-TPA. Hasil penelitiannya menyatakan bahwa ada perbedaan prestasi yang signifikan antara kedua jalur tersebut. Hasil penelitian ini juga sejalan dengan kesimpulan yang diperoleh dari riset yang dilakukan oleh Djudin (2018) dan Widiastuti, dkk (2014) yang membandingkan prestasi belajar mahasiswa berdasarkan seleksi masuk penerimaan mahasiswa baru. Hasil penelitiannya yaitu ada perbedaan prestasi akademik ditinjau dari jalur masuk. Prestasi akademik mahasiswa jalur SNMPTN lebih tinggi dari mahasiswa jalur SBMPTN dan Mandiri. Hasil yang berbeda justru ditemukan oleh Lodang dan Palennari (2010) yang meneliti perbandingan prestasi akademik mahasiswa Jurusan Biologi ditinjau Jalur PMJK/PMDK dengan SPMB. Hasil penelitian menunjukkan bahwa tidak ada perbedaan prestasi akademik mahasiswa jalur PMJK/PMDK dengan jalur SPMB.

\section{Analisis pengaruh jalur penerimaan mahasiswa baru terhadap masa studi mahasiswa}

Terkait pengaruh jalur penerimaan mahasiswa baru berpengaruh terhadap masa studi mahasiswa, diperoleh hasil uji parsial dengan nilai Sig. sebesar 0,01. Ini menunjukkan bahwa ada pengaruh jalur seleksi yang signifikan terhadap masa studi. Hal ini sejalan dengan hasil penelitian Munawaroh (2015: 72) dan Wulandari (2015) yang mengatakan bahwa ada pengaruh jalur masuk terhadap prestasi mahasiswa. Hal ini terlihat dari IPK mahasiswa yang dibedakan berdasarkan jalur masuk PTKI. Temuan ini mengindikasikan bahwa pada jalur masuk PTKI tertentu, mahasiswa memiliki kemampuan yang lebih yang signifikan.

\section{Perbedaan prestasi belajar mahasiswa ditinjau dari jalur penerimaan mahasiswa baru}

Berdasarkan Tabel 2, ditampilkan hasil uji ANOVA perbedaan IPK antara tujuh jalur penerimaan yaitu SPAN-PTKIN, UM-PTKIN, MANDIRI TES, MINAT/BAKAT, SBMPTN, SNMPTN, PSSB. Dari tabel tersebut dapat kita lihat bahwa nilai Sig. diperoleh nilai $\mathrm{p}(\mathrm{p}$-value $)=0,000$. Dengan demikian pada taraf nyata $5 \%$ kita menolak Ho, sehingga kesimpulan yang didapatkan adalah terdapat perbedaan yang bermakna rata-rata IPK berdasarkan ketujuh jalur penerimaan tersebut. Hasil penelitian ini sejalan dengan kesimpulan yang diperoleh Suherman (2013) yang menyimpulkan bahwa secara keseluruhan rata-rata IPK mahasiswa yang diterima di jurusan matematika FMIPA UNP Padang untuk tahun masuk 2010, jalur masuk bidikmisi berbeda secara nyata dengan jalur masuk lainnya. Sedangkan untuk tahun 2011, ternyata rata-rata IPK jalurmasuk regular berbedasecaranyata dengan jalur masuk lainnya.

\section{Perbedaan masa studi mahasiswa ditinjau dari jalur penerimaan mahasiswa baru}

Pada Tabel 3, ditampilkan hasil uji ANOVA perbedaan masa studi antara tujuh jalur penerimaan yaitu SPAN-PTKIN, UM-PTKIN, MANDIRI TES, MINAT/BAKAT, SBMPTN, SNMPTN, PSSB. Dari tabel tersebut dapat kita lihat bahwa nilai Sig. diperoleh nilai $\mathrm{p}(p$-value $)=0,000$. Dengan demikian pada taraf nyata $5 \%$ kita menolak Ho, sehingga kesimpulan yang didapatkan adalah terdapat perbedaan yang bermakna rata-rata masa studi berdasarkan ketujuh jalur penerimaan tersebut. Hal ini terjadi dikarenakan masa studi berkaitan erat dengan prestasi belajar mahasiswa (IPK). Semakin baik prestasi belajar mahasiswa, maka masa studi nya semakin cepat, begitu juga sebaliknya.

Perbedaan rata-rata masa studi ini disebabkan oleh beberapa faktor, salah satunya yaitu prestasi mahasiswa sebelum masuk ke perguruan tinggi. Hal ini terlihat dari rata-rata masa studi yang tertinggi yaitu pada mahasiswa yang masuk perguruan tinggi melalui jalur SNMPTN. Jalur SNMPTN merupakan jalur masuk khusus yang diperuntukkan bagi siswasiswa berprestasi di sekolah asalnya dan tidak memerlukan tes masuk perguruan tinggi. Hal ini tentu berkaitan erat dengan bagaimana pengelolaan waktu dan cara belajar mahasiswa 
ketika di bangku perkuliahan. Secara tidak langsung, pembiasaan di sekolah lama tentu mempengaruhi prestasi belajar dan tentunya masa studi mahasiswa di perguruan tinggi.

\section{Kesimpulan}

Berdasarkan hasil analisis dan pembahasan di atas diperoleh kesimpulan bahwa: (a) hanya faktor jenis kelamin dan jalur PMB yang berpengaruh signifikan terhadap prestasi mahasiswa; (b) Ada empat dari tujuh faktor yang secara signifikan mempengaruhi masa studi, yaitu jenis kelamin, jenis sekolah tinggi, IPK, dan jalur PMB; (c) Terdapat perbedaan prestasi mahasiswa yang signifikan ditinjau dari hal jalur penerimaan mahasiswa baru; (d) Terdapat perbedaan masa studi yang signifikan dilihat dari jalur penerimaan mahasiswa baru; dan (e) Terdapat korelasi negatif yang sangat signifikan antara IPK dan masa studi.

\section{Saran}

Saran yang disampaikan berdasarkan hasil penelitian ini bagi pihak kampus antara lain adalah; (1) memberikan alternatif pemilihan dan faktor penentu prestasi akademik dan mahasiswa; (2) menjadikan bahan pertimbangan dalam menentukan perencanaan penerimaan mahasiswa baru; dan (3) membantu penentuan kuota tiap seleksi. Sedangkan saran yang disampaikan berdasarkan hasil penelitian ini bagi mahasiswa antara lain adalah: (1) memberikan gambaran faktor-faktor apa saja yang mempengaruhi masa studi mahasiswa; dan (2) mengoptimalkan dan memperbaiki faktor yang dapat meningkatkan prestasi belajar mahasiswa. Namun, perlu dikaji lebih lanjut faktor-faktor lainnya yang mempengaruhi keberhasilan studi mahasiswa, tidak hanya dari faktor jalur PMB, namun bisa faktor eksternal maupun internal lainnya.

\section{Daftar Pustaka}

BAN-PT (2011), Buku VI Matriks Penilaian borang dan evaluasi diri Akreditasi Institusi Perguruan Tinggi (AIPT), tersedia secara online di https://www.banpt.or.id/

Djudin, T. (2018). Analisis Prestasi Akademik dan Lama Studi Mahasiswa Lulusan Jurusan PMIPA FKIP Universitas Tanjungpura Ditinjau dari Jalur Masuk dan Program Kuliah. Jurnal Pendidikan Matematika dan IPA, 9(2).

Fitrah, M. (2015). Mengidentifikasi Faktor Penghambat Guru Matematika Kecamatan Dompu NTB terhadap Proses Pembelajaran pada Sekolah Menengah Atas. Jurnal Kependidikan, 1(1), 73-88.

Gozali, N., \& Nasehudin, T. S. (2012). Metode Penelitian Kuantitatif. Bandung: CV Pustaka Setia.

Hijazi, S.T. and Naqvi, S.M.M.R. (2006). Factor Affecting Students' Performance: A case of Private Colleges. Bangladesh. E-journal of Sociology, 3(1).

Lodang, H. \& Palennari, M. (2010). Perbandingan Prestasi Akademik Mahasiswa Jurusan Biologi Jalur PMJK/PMDK dengan SPMB. Bionature, 11(1), 50 -53.

Mckenzie, K. and Schweitzer, R. (2001). Who succeeds at University? Factors Predicting Academic Performance in First Australian University Students. Higher Education Research and Development, 20(1), 21-33.

Muslimin, Z. I. (2012), Prestasi Belajar Mahasiswa yang Ditinjau dari Jalur Penerimaan Mahasiswa Baru, Asal Sekolah, dan Skor Potensi Akademik. Jurnal Penelitian Psikologi, 3(1), 381-393.

Muspawi, M., Pratama, R., \& Sarlles, M. (2020). Kontribusi Praktek Kerja Industri Dan Kemampuan Akademis Terhadap Persepsi Siswa Tentang Kesiapan Memasuki Dunia Kerja. Jurnal Kependidikan: Jurnal Hasil Penelitian dan Kajian Kepustakaan di 
Bidang Pendidikan, Pengajaran dan Pembelajaran, 6(3), 490-501. doi:https://doi.org/10.33394/jk.v6i3.2772

Nalim. (2015). Analisis komparatif dan eksploratif terhadap kualitas Pelayanan bank syariah dan bank konvensional di Kota Pekalongan. Jurnal Hukum Islam (JHI), 13(2), 108118.

Nalim, Pramesti, S.L.D. (2020). Faktor-Faktor yang Mempengaruhi Prestasi Akademik Mahasiswa. Jurnal Pendidikan, 21(1), 1-17.

Rahmi, I. \& Yozza, H. (2020). Analisis Kausal Masa Studi Mahasiswa Program Studi Matematika Universitas Andalas dengan Menggunakan Metode Cart. Jurnal Matematika, Sains, dan Teknologi, 21(1), 22-34.

Saputro, M., Ardiawan, Y., \& Fitriawan, D. (2015). Faktor-Faktor yang Mempengaruhi Prestasi Belajar (Studi Korelasi pada Mahasiswa Pendidikan Matematika IKIP PGRI Pontianak). Jurnal Pendidikan Informatika dan Sains, 4(2), 233-246.

Suherman. (2013). Studi Tentang Pencapaian Hasil Belajar Mahasiswa Jurusan Matematika FMIPA UNP Menurut Jalur Masuk. Prosiding Semirata FMIPA Universitas Lampung, Lampung.

Sulasmi, E. (2020). Analisis Faktor-Faktor yang Mempengaruhi Prestasi Belajar Ditinjau dari Aspek Manajemen Minat Belajar Siswa. Jurnal Manajemen Pendidikan Dasar, Menengah, dan Tinggi (JMP-DMT), 1(1), 10-17.

Suryabrata, S. (2001). Psikologi Kepribadian Cetakan ke 4. Jakarta: Raja Grafindo Pustaka.

Suwena, Kadek Rai. (2017). Jalur Penerimaan Mahasiswa Baru Bukan Penentu Prestasi Belajar Mahasiswa. Ekuitas Jurnal Pendidikan Ekonomi, 5(2), 1-10.

Syafi'i, A., Marfiyanto, T., \& Rodiyah, S.K. (2018). Studi tentang Prestasi Belajar Siswa dalam Berbagai Aspek dan Faktor yang Mempengaruhi. Jurnal Komunikasi Pendidikan, 2(2), 115-123.

Yuzarion. (2017). Faktor yang Mempengaruhi Prestasi Belajar Peserta Didik. Jurnal Ilmu Pendidikan, 2(1), 107-117.

Widiastuti, A., Sugiharyanto, \& Wibowo, S. (2014). Perbedaan Prestasi Belajar Mahasiswa Pendidikan IPS FIS UNY. Socia: Jurnal Ilmu-Ilmu Sosial, 11(2), 119-129. 